\title{
PASSION FOR PUTIN'S PALACE: POLITICAL PROTESTS IN MODERN RUSSIA
}

On January 23, 2021, protests in support of Alexei Navalny were held in more than 100 Russian cities. A great public outcry was caused by the Anti-Corruption Foundation A. Navalny's investigative film that appeared on the Internet about the palace of Vladimir Putin on the Black Sea coast near Gelendzhik. Inconsistent with the authorities protests were quite resonant. As a result, about 4,000 people were detained. Subsequently, the authorities were forced to comment on this investigation. It followed from the commentary that V. Putin had nothing to do with this palace. Some time later, even its owner, a businessman close to V. Putin, Arkady Rotenberg, appeared. The belated confession looked strange to say the least, and could hardly reassure those Russians who were shocked by this investigation. Inconsistent with the authorities protests took place on January 31, 2021. Unlike the previous all-Russian action, the authorities carefully prepared for them. The new protests were less resonant. The security forces acted more decisively against the protesters.

So, on January 31,2020 , more than 5,000 people were already detained. On February 2, 2021, after the announcement of the court's verdict to A. Navalny, the security forces very harshly dispersed the people who had begun to gather in support of Navalny. Force was even used against journalists. Navalny's staff was forced to take a tactical pause and, for a while, announce the refusal of protests in the winter of 2021. The flashlight promotion for Valentine's Day (February 14, 2021) looks rather like an exception here.

These performances, which spread to almost all major cities of Russia (and even to the provinces), can be considered very indicative. Recently, there has been stagnation in the political space of public activity. The Russians were forced to watch the dramatic events of the confrontation between society and the authorities in Belarus. Does this mean that the Russian government did not give a reason for such statements? Most likely no. Although, the regime of A. Lukashenko and V. Putin has a lot in common.

In fact, in Russian political discourse there has not been such a unifying protest theme for a long time, capable of mobilizing the active population of large cities and provinces at some point in time. An unusual situation has developed for the Russian regime when "successful examples of street pressure the government always leads to new attempts" (Shults, 2018: 239).

The dynamics present in the Russian protests in the winter of 2021 promises to be nervous for the Russian authorities. In September 2021, elections to the State Duma will be held in Russia. A surge in protest activity can be expected in connection with this event. 


\section{FEATURES OF POLITICAL PROTEST IN THE RUSSIAN PROVINCE}

The standard of living in Russian regions is gradually getting lower. Russian youth have more and more reasons to feel abandoned and lacking serious career and life prospects. Increasingly, young people experience the dissonance between reality, created by the official media and their own experience. The contradictions in the perception of reality do not favor the Russian authorities. It becomes clear that it is impossible to live based solely on the positive reality constructed by the federal media. Euphoria from the 2014 Olympics, V. Putin's geopolitical tactics, presented as unconditional achievements, have lost their potential, leaving young people alone with the need to survive. Life strategies today can be implemented only in close contact with the authorities, integrating into their projects.

The protest agenda has long been accumulating in Russian regions. For a specific reason, young people could not understand the consequences of the pension reform. Meanwhile, in small cities of Russia, the increase in the period of retirement leaves a huge number of people literally on the verge of existence. Small provincial locuses can increasingly be seen in the list of protesting Russian towns. The protests are taking over towns with a population of about 20,000. Monotowns are often such locuses. Reducing the economic activity of the population is a sure way to actualize the protest scheme. Increasingly, provincial youth are forced to leave to work in Moscow and other large cities. Russian youth are deceived by expectations of quick adaptation to the new economic reality. There may be debate among researchers about the extent to which such labor migrants can pose a threat to public order and how quickly they can adopt a protest political agenda. "Migration to urban centers is associated with an increase in people's anticipation to an unsatisfactory high level, and therefore leads to violence" (Garr, 2005: 149).

Dissatisfaction with the federal government is formed by regional and municipal cases. Officials more and more often demonstrate by personal example how to break away from the common people. Synchronized protest actions in the Russian regions deserve attention, if only because in the regional political space of Russia it is much more difficult to articulate their claims against the regime than in the capital. The necessary anonymity can be ensured in the capital. A single person can easily get lost in a large active crowd. It is much more difficult to do this in the conditions of the regions of Russia. Participation in a protest event, especially an unsanctioned one, turns into a much more courageous enterprise. On the other hand, the security forces may act more loyally towards the protesters. In the provinces, many are relatives and friends. As already noted, all protest cases are united by dissatisfaction with the political regime and its specific representatives. Discontent easily turns into more active protest.

This contributes to the accumulation of anger and its transfer to protest condition. German political and social philosopher Max Scheler definit it as "ressentiment," which "lingering and crowding-out" (Scheler, 1999: 20).

A feature of the protests on January 23, 2021 was their massiveness and wide geographical coverage. Protests took place in almost all Russian regions, with the excep- 
tion of the North Caucasus. ${ }^{1}$ The protests in Crimea looked rather unexpected. Simferopol and Sevastopol have become new centers of protest activity. This synchronicity deserves an examination of the motives behind it.

Up to this point, protests in Russian regions differed greatly in their agenda. In addition, they took place at different times. There was no synchronization in the protests. For several electoral cycles in Russia, regional election campaigns in the Russian Federation have been held at different times. The protests on January 31, 2021 were already different from the first protest in 2021. There is a clear difference in the number of people who participated in the protests.

Almost all media (official and independent) give different estimates of the number of protesters/detainees. We focused on the median data received from different media in different cities. We used data from such publications as "Kommersant," RBC, "Novaya Gazeta" and some regional media. Some institutions monitoring protests in Russia found useful information (Rovnensky, 2021). The number of protesters in Russian cities is also difficult to estimate because their number is constantly changing. The protesters are dispersed within the same city, and are not located in one place. There are still no official data for some regions, and they had to be asked in an unofficial discourse (The exact data on those..., 2021; The number of people detained..., 2021).

Table 1

Dynamics of protest activity. Russian regions. January 23-January 31, 2021

\begin{tabular}{||l|c|c|c|c|c|c|c|c||}
\hline \hline & Voronezh & $\begin{array}{c}\text { Yekater- } \\
\text { inburg }\end{array}$ & Kazan & $\begin{array}{c}\text { Nizhny } \\
\text { Novgorod }\end{array}$ & Lipetsk & Perm & Omsk & Khabarovsk \\
\hline 23.01 .2021 & $1000 / 101$ & $10000 / 20$ & $3000 / 243$ & $10000 / 91$ & $1000 / 38$ & $8000 / 4$ & $1500 / 24$ & $300 / 74$ \\
\hline 31.01 .2021 & $1000 / 122$ & $10000 / 83$ & $1500 / 400$ & $1500 / 182$ & $100 / 9$ & $1000 / 83$ & $1000 / 62$ & $100 / 13$ \\
\hline
\end{tabular}

Source: Statistics were taken from city news portals: dvnovosti.ru, gorod48.ru, kazanfirst.ru, kommersant.ru, properm.ru, ngS55.ru, newsNN.ru, E1.ru. We used materials from a resource ovdinfo.org, specifically taking into account the number of detainees.

The table show that Russian regions are politically revitalized in different ways. Their prospects may depend on how much the government itself and the political opposition are initially ready for compromises. Much depends on the preparation for the protests by the authorities themselves, and on the attitudes towards the work of the security forces with the protesters. As we will see, the January 31, 2021 protests are already significantly different from the January 23, 2021 protests. The violence used played a role. The security forces acted much tougher. The number of detainees has increased in the regions of Russia.

Power could initially intimidate potential participants. The situation when in some Russian schools, instead of V. Putin, students began to hang a photo of A. Navalny, provoked a powerful repressive response. Classroom hours were held in schools, conversations with young people, parent meetings. Regional TVs ran talk shows condemning the protest. Loyal experts did their best to convince the audience of the inad-

${ }^{1}$ Nevertheless, in some cities of the North Caucasus, protests still took place. There were not too many protests in Maikop (Adygea), Makhachkala and Izberbash (Dagestan), Nalchik and Prokhladny (Kabardino-Balkaria), Ardon (North Ossetia). 
missibility of inconsistent with the authorities protests. Youth were invited to skating rinks and to the cinema, luring them with ticket discounts. So, in Lipetsk, youth were invited to the Zoo for free. In many regions of the Russian Federation, there have been demonstrative detentions of famous journalists and bloggers. The authorities' pressure on education is confirmed by examples of dismissal from universities of teachers who participated in the protests. In some universities, dropping out of active students followed.

Some researchers associate the growth of student protest activity with the state of the political regime itself (Zakharov, 2017: 51). Russia is no exception. Periods of political uncertainty facilitate political mobilization. On the other hand, the more stable the political regime and the stronger the power, the less chances students have for mobilization.

Based on the research of several authors, it can be seen that many new faces appear in the protest. Every third person who participated in protests did it for the first time (More than a third of those..., 2021). The protest is getting much younger. This can be seen in photos from all regions where the protests took place.

The scale of protest activity in the Russian regions is so critical that the authorities restrict the work of the infrastructure. This affects almost all residents. City centers restrict the movement of citizens. In places of alleged protests, leisure facilities and cafes are temporarily closed. In large cities, the metro is suspended during the protests. Trams, trolleybuses and buses stop moving. In Chelyabinsk, there were interruptions in access to the Internet. Power by all means protects protest from a possible expansion of the social base. Thus, the ring around the alleged protesters narrows. But even these measures do not help the protests to remain a matter of a specific political locus. A public display of disagreement becomes the subject of discussion and widespread public reaction. Protests cannot be silenced and hidden. This is another distinctive feature of the 2021 protests.

\section{THE AGENDA OF REGIONAL PROTEST IN MODERN RUSSSIA: GENERAL AND SPECIAL}

Once, Émile Durkheim noted: "the power of imitation is forced by the moral authority of the big centers" (Durkheim, 2020: 135). E. Durkheim's thesis seems very important to us. Until recently, protests in Russian regions were quite rare. Moscow set the tone in the direction of the protest genre. In part, it was St. Petersburg. The protests in the Russian provinces mimic the protests in the capitals in style and aesthetics. Such a connection can only be present when it comes to the federal context of protests. If the protests have one common idea.

The size of the Russian state suggests that each region has its own unique cultural, economic and social landscape. In each subject of the Russian Federation, regional political regimes have been formed, which are perceived and supported in different ways by society. Therefore, each region of Russia may have its own problems. They may be enough for instant articulation in the political sphere. The events in some constituent entities of the Russian Federation that preceded the outburst of protest 


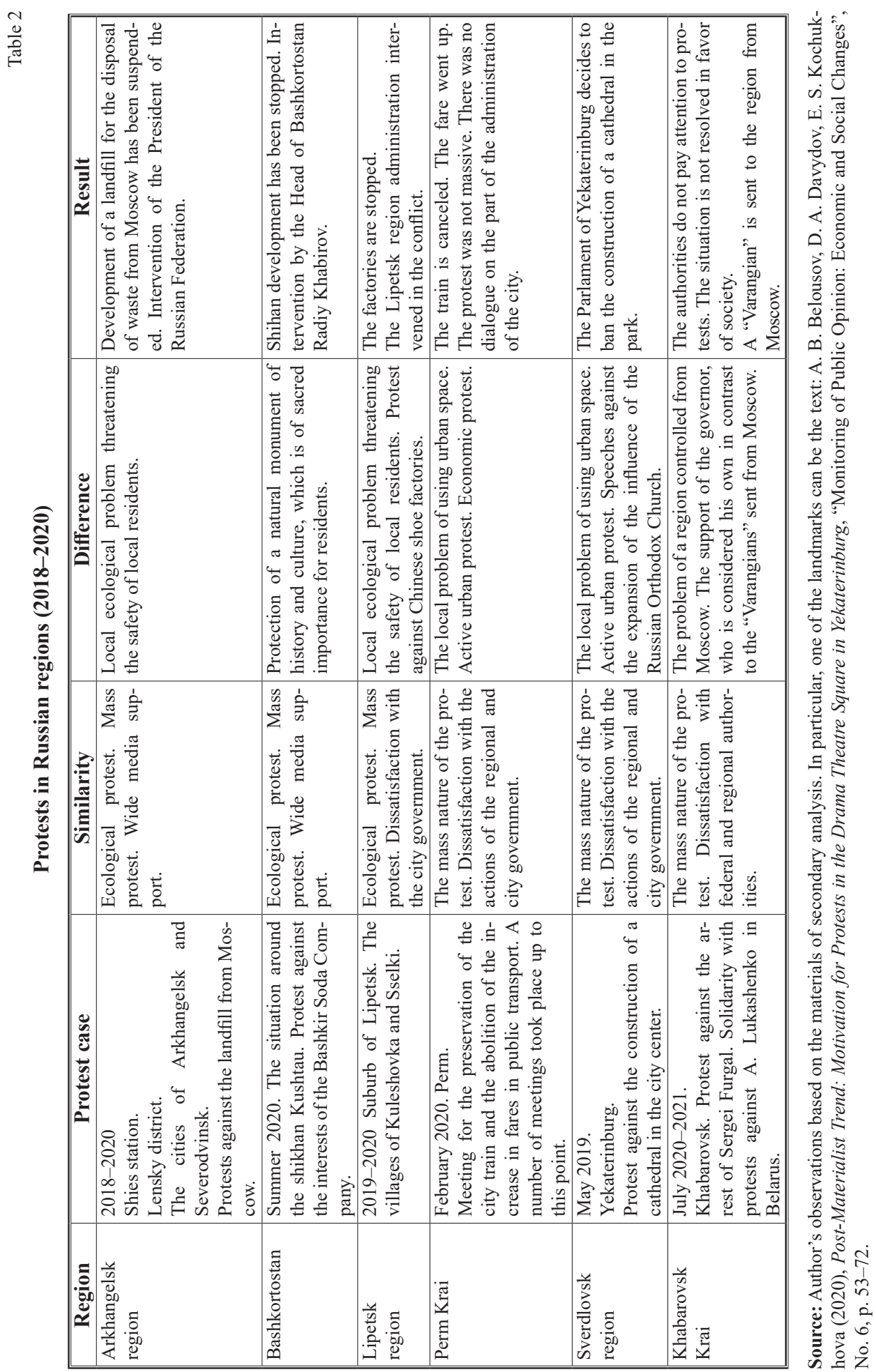


energy on January 23, 2021 deserve special attention. Despite the fact that protest actions have remained in history at this point in time, the protest potential itself does not go anywhere. It accumulates for articulation on new political irritants. Each case of regional protests in Russia has its own general and special aspects that allow bringing the events themselves closer together. Also, they can be differentiated depending on motives and goals.

In the table we can see the general and special aspects of the protests in the constituent entities of the Russian regions (2018-2020). The presented protest cases have different geography and differ markedly in their plot features. Of course, the table does not take into account all protest events that took place in Russian regions. The emphasis is placed on the most resonant events that have become the subject of discussion at the federal level.

As we can see, the activists have so far managed to defend those objects that they had to protect from the encroachments of influential economic actors and the authorities that are interested in their presence. High public outcry contributed to a gradual change in the position of local and regional authorities supporting the parties, based on their considerations of tactical superiority.

The authorities in the regions were afraid to continue protests. It was clear that each new decision could increase uncertainty and escalate tensions. Regional protests in Russian regions, which took place until 2021, can be called massive and threatening the legitimacy of regional authorities. The risks of delegitimation for the regional authorities can be so high that the resignation of the governor can be a logical result of the out of control protest activity. A similar example has already been in the Arkhangelsk region. After the protests of Shies, the governor Igor Orlov was resigned. The change of the governor took place in the Perm Krai, and new governor Dmitry Makhonin has to solve the problems of the city train and high protest activity of the towns people instead of Maksim Reshetnikov.

The general plan of regional protests may be their environmental orientation, or a negative reaction of the public to the ongoing changes in the urban infrastructure. Demands to stop illegal development are becoming private subjects of regional and municipal protests. Such problems exist in almost every of the Russian regions.

The common side may be the absence of any political demands. So, we do not see regional protests related to the topic of election campaigns. Systemic political actors involved in regional politics prefer not to escalate protests. Today in Russia there is a consensus between parliamentary parties and their leaders.

The similarity of protest actions can be determined by the coincidence in the social base of the protest, in which we can see practically all urban society in the context of schoolchildren, students, workers and entrepreneurs, unemployed and pensioners. The protest has male and female faces.

The generality of protest cases can be achieved due to the coincidence in the assessments of the federal agenda and the problems arising from it. These were the rallies in the constituent entities of the Russian Federation about the pension reform. In some cases, the rallies were decorative.

Continuing the search for common ground in regional protests, once can see that the authorities may experience a deficit of repressive resources to suppress the protest. 
Then parallel structures come to help. Some researchers see attempts to address them as not very positive symptoms for the authorities themselves. The authorities alone cannot cope with protest activity. So, S. Zakharov said, "the creation of parallel structures under the patronage of the authorities is a symptom of the crisis of the legitimacy of the ruling regime" (Zakharov, 2014: 138). In this case, we can see the opposite effect of the functioning of parallel structures, usually perceived as part of civil society and one of the important subjects of democratization. It turns out exactly the opposite. Parallel structures work to suppress protest. When protests are dispersed by the authorities, there is a high probability that employees of private securities structures and "titushki" - local athletes loyal to the authorities.

Power is always in the ring of the most loyal people who protect and protect it, following the Elias Canetti, from a "sudden touch" (Kanetti, 1997: 18-21). The actions of an angry mob can always pose a threat to any authority.

The differences between regional protests in modern Russia can be seen in their different results. Protesters are not always satisfied with the results of their resistance.

In some cases, the protest reached its goal (Arkhangelsk region, Bashkortostan, Ekaterinburg). In some cases, the protest mass was not enough for the authorities to see it as a risk to their own legitimacy. Therefore, the situation has not yet been resolved positively for the protest (Perm Krai, Khabarovsk Krai).

More and more often in the Russian regions one can see "Varangians." This is how some researchers define the envoys of Moscow and those representing the interests of state corporations. There are "procedural differences in the mechanisms of empowerment" between "Varangians" and "local" (Podvintsev, 2014: 119). Local elites in some regions may feel resentful at the same time. In some cases, the phenomenon of the "Varangian" only intensifies the protest moods (Khabarovsk Krai).

Projecting the histories of regional protests presented in the table, one can see that the most massive protests on January 23, 2021 could just take place in Russian regions, where protest activity has already been noted. Apparently there is a certain part of citizens in them, for whom the activities of the authorities are a strong irritant. That is why they can protest regardless of the agenda.

In the case of the protests on January 23, 2021, the protest potential of various groups of the urban population is mixed. The protest volume is expanding due to the mixing of regional and federal protest agenda. It is no coincidence, as already noted, that many citizens are taking part in such protest activity for the first time (More than a third of those..., 2021). Offline and online protests mix. It becomes rather difficult to assess the scale of the dissenting activity. The opponent of power constantly eludes definition.

The leaders of the parliamentary factions in Russia also saw the risks of integrating the protest potential of various social groups, united by the investigation of Alexei Navalny's Anti-Corruption Foundation. G. Zyuganov, S. Mironov and V. Zhirinovsky turn to their supporters in turn. The threat of a large left electorate merging in the protest mass of A. Navalny's supporters seemed quite real. Unexpectedly, the actions of A. Navalny were criticized by Grigory Yavlinsky - the leader of the "Yabloko." Despite the fact that the party today is non-parliamentary, it still has current deputies in many regional and city parliaments. 
The reaction of the party leaders in Russia is not very consistent with the real state of affairs. A large mass of Russians perceived the latest events in Russia extremely negatively. The Russians understood a significant deterioration in the level of their well-being, which was dangerous for the stability of the political regime in Russia.

\section{POLITIVAL PROTESTS AND CARNIVAL ENERGY}

The radicality of a protest can always be masked by its carnival dresses. Behind the external fun and joy, irony and farce, you can see your own special drama, which seriously puzzles the authorities in modern Russia. In general, as we have already noted in one of our early studies, the authorities themselves may be interested in the maximum carnivalization of politics. Society should be relaxed, gentle, and capable of being ironic about problems. For the authorities, such a state of public minds is optimal. It allows it to be ruled further without being puzzled by the effects of the policy being pursued. Carnival mixes everything up and gives everything a touch of humor. It should be noted that there is a relationship between the legitimacy of the authorities and the ability of society to adequately understand the rules of carnival reality, imposed "from above."

So, "the legitimacy of a regional leader (governor) begins to depend on how much he is able to create a festive mood" (Skiperskikh, 2020: 28).

The history of Russia shows that society is accustomed to carnival. In such conditions of reality, following Yu. Lotman, "the theater invaded life, actively rebuilding the everyday behavior of people" (Lotman, 2015: 267). The authorities in Russia show the society an example of ironic answers to problematic questions. "The courtyard itself is a single whole and is able to broadcast its behavior patterns to the most remote corners of the country," noted the Italian political philosopher M. Viroli (Viroli, 2014: 28). Dmitry Peskov's comments on the investigation of A. Navalny, and the answers of V. Putin himself, show that they understand this challenge in a largely frivolous and maximally ironic way.

In the case of protest activity we are analyzing, it is important to identify the subject of the carnival initiative. There is a change in the subject, offering his own direction of the event. If earlier the authorities acted for them, holding numerous festivals and fairs, arranging shows and fireworks, today it is already society itself. If once the government itself arranged holidays for society, independently determining and planning their calendar sequence, then today the society shows interest in a different holiday agenda.

Taking part in unauthorized protests, society changes the usual direction of the total performance. Guy Debord said, "the performance is a model of the prevailing way of life in society" (Debor, 2011: 10). The protests are destroying the dynamics of the performance, which is customary for the authorities. An alternative is being created, with other directors, actors, with different goals. And it is in this new, alternative project that the confused authorities are involuntarily included.

Ironically, the carnival masks of the Russian protests on January 23 and 31, 2021 are being replaced today with protective masks. The protests took place during the 
period of restrictive measures COVID-19. The risks of a pandemic do not deter protesters, which shows the deep reserves of the inner energy of the protest. This potential for protest needs to be explored. Masks help both the authorities and the protesters themselves, making it difficult to identify the direct participants in street protests. The masks are being saved from public obstruction. They protect the Protestants from possible persecution by the authorities and numerous directors and heads of budgetary institutions. By the way, the authorities remind participants of violations during street performances precisely in connection with the restrictions of COVID-19. There are "sanitary" cases, according to which activists close to A. Navalny are being tried. The authorities are guided by the well-known statement of I. Stalin: "if there were a man, there would be a criminal case."

A huge number of Russians took to the streets of Russian cities. Many of them, indeed, ironically presented their participation in the protests. This could be seen from the humorous inscriptions on the posters that the protesters brought with them. Of course, the language of the posters requires a separate study, but in almost every poster one could see a dismissive, familiar questioning of the authorities, an attempt to dialogue with them on an equal footing. Following M. Bakhtin, a situation is created where activity of people is associated "with a theatrical stage, with an areal spectacular mask" (Bakhtin, 1975: 172). As a matter of fact, the behavior of A. Navalny, which appeals to a certain part of Russians, is precisely familiar behavior. This is proved by his numerous public appeals to Vladimir Putin.

Such a regime may well be attributed to a carnival situation, when the top and bottom are mixed. Power instantly loses its authority and no longer appears to be a formidable, frightening force. Instead of an authoritarian repressive reality, a democratic reality arises, where everyone has the right to their own voice and to demonstrate their own position. At one time, a set of similar strategies of subjects in a single test space were called by M. Bakhtin - "polyphony." Polyphony is a collection of not only individual voices that have the right to exist. It is also political and civic positions that are adjacent to each other. The monopoly of power in carnival discourse is lost. The key is the very principle of polyphony, releasing the will of an individual participant in the event.

Looking at the protests on January 23-31, 2021, you can see various examples of the existence of carnival forms. "Top" and "Bottom" can be mixed. These are the principles of the carnival genre. "High" and "low" were initially formed by the authorities themselves, as specific prescriptions and "rules of the game," following the German political philosopher Aleida Assmann, "are established through violence" (Assmann, 2016: 184). Any hierarchy created in the political space is the result of this violence. Therefore, the carnival energy out of control easily destroys any hierarchy. "Top" becomes :Bottom." "High" and "Low" mix. Paraphrasing the well-known text of the "Internationale," "who was nothing, in the conditions of the carnival can become everything."

The transition of a peaceful protest into an aggressive and agitated state does not mean favorable prospects for actors opposing each other. The public is at risk of serious injury. For the authorities there is a risk of losing their legitimacy by switching to forceful and repressive practices of suppressing civil activity. We have already seen 
this in the recent example of the breakdown of the Belarusian security forces, who keep the unpopular regime of A. Lukashenko from erosion. It should be noted that there is a strong symbolic and factual connection between V. Putin and A. Lukashenko. Russia and Belarus are almost the only strongholds of the empire in the post-Soviet space. V. Putin and A. Lukashenko are not going to share power. For the opposition, there are risks that its protest can be suppressed at the very beginning. There may not be resources to replenish it, because the authorities can intimidate society. It is important to make it clear to the public that the authorities will not be inclined to excessive sentimentality towards those who are trying to undermine its foundations.

\section{PASSION FOR PUTIN'S PALACE: CARNIVAL REACTION}

In the Russian political tradition, there are few examples of soft, "velvet" transitions from one form of political structure to another. Any political transformation turns out to be a difficult test for all actors in the political process. For some subjects, it means the destruction of a stable basis. For others, it is a chance for change. The cultural theorist Vyacheslav Ivanov drew attention to this when he contrasted Apollo with Dionysus. For Russia, Dionysus is more characteristic, meeting the carnival expectations of Russian society. In Russian culture, society languishes in anticipation of a carnival. The patience of a Russian person is associated precisely with the expectation of the moment when one can relax. Dionysus is less governable than the beautiful, noble Apollo. Dionysus, unlike Apollo, practically does not know the sense of proportion, and it is always difficult for him to stop. Once, V. Ivanov noted that "Dionysus is dangerous in Russia: it is easy for him to appear here as a destructive force, fury" (Ivanov, 1994: 83).

Looking at some examples of Russian protests on January 23, 2021, one can see how passions over the discovered palace of V. Putin unleash the carnival energy of society. Society enters into familiar contact with the authorities. Power no longer commands respect. Respect is a thing of the past. This is confirmed by the content of the posters showing a high degree of Protestant creativity. Real discontent and bitterness with the emerging political situation is always masked behind the playful character. In fact, the roles within the carnival are very clear.

Any Protestant becomes equal to the President, as he allows him to criticize. Familiar contact is felt during clashes with riot police. The culmination of mixing "top" and "bottom" can be a game of someone from the protesting crowd in football with the helmet of one of the policemea. In Moscow, young people attacked a special FSB car with snowballs, blocking it for a while. In the Russian tradition, playing snowballs is an obligatory part of festive activity. They usually throw snowballs at the stuffed carnival, the farewell of which heralds the imminent arrival of spring. The painting of the Russian painter Vasily Surikov "Taking the Snow Town" shows an episode of the heroic game that was once popular in Siberia. The noise and glee of the crowd seem to rush at the viewer through a snow mass. It should be noted that the protests on January 23, 2021 in some Russian regions could not be deterred even by a severe frost. Somewhere frosts reached 30 degrees Celsius. So, the protest on January 23, 2021 in 
Yakutsk took place at a time when the thermometer showed -51 degrees. On January 31, 2021, in Yakutsk, protesters came out at -41 degrees.

In carnival reality, there is always an adventurous beginning. Adventurism, in part, is associated with the search for adventure, including life-threatening ones. For example, at protest rallies in Yekaterinburg, security forces pushed the protesters onto the ice of the city pond. In Vladivostok, riot police expelled protesters onto the ice of the Amur Bay. There was a clear threat to the lives of both the protesters and the security forces themselves.

Passions about V. Putin's palace are played out in playful metaphors of the palace itself. A. Navalny significantly enriches the latest political language in his work. Political discourse develops due to the comprehension of the new political reality. A new language of resistance is being developed. This is the language of the Russian carnival of 2021. "Mud room," "Aquadisco," "Toilet brush," "Bunker" - these concepts began to be actively used by Russians in common discourse. People in crowns appear in the symbolic field of protest, with toilet brushes in their hands. Suffice it to recall how after watching A. Navalny's investigative film about D. Medvedev "He's not Dimon for you," yellow toy ducks suddenly became a symbol of the 2017 protests.

The protest is revealed through various genres. Poems and songs appear. City surfaces are covered with protest tags. Russian protests are the subject of numerous cartoons. Each such creativity can be viewed in the context of laughter culture. Power is ridiculed and not taken seriously. The authority of the authorities was significantly shaken.

It should be especially noted that the 2021 protest finds itself in a situation where it can use the chances of digital development. Social media is a huge support for the protest. So, in the January protests of 2021, the social network TikTok was of great importance, expanding the number of A. Navalny's supporters among Russian schoolchildren. The difference between today's protests in Russia and the wave of protest activity in 2011-2012 is much deeper integration into social networks. Today, almost all protesters have telephones with cameras that allow them to instantly record their own participation in the protest event. You need to understand that young people everywhere are interested in "hype" and their own promotion, modeling their own heroism. Russian youth is no exception. Participation in protest events is becoming a significant event in his personal biography.

The picture of what is happening is instantly recorded from different angles and sent to the Internet. At the same time, a person integrated into digital reality turns out to be its hostage as well. The validity of this thesis is proved by the huge number of facts that unlawful actions were exposed after the events had taken place.

\section{INSTEAD OF CONCLUSIONS}

The protest actions in January 2021 in Russia are still difficult to assess in terms of their potential. The protest becomes fluid, flexible, and it is difficult to predict how dynamic it might be. There is a feeling that the protests resemble the events in Belarus, which with each new announcement became more boring and fewer in 
number. In the case of Russia, we are dealing with inconsistent with the authorities protests. Protest actions have managed to accumulate a high social potential. Some people do not participate in protests, although they may support those who do. As Noam Chomsky noted, "A lot of things we would like to say may be very hard to express" (Chomsky, 2003: 107). Perhaps more compelling reasons are boring for wider popular protests. In our opinion, the rejection of the protests of A. Navalny's staff may promise an even more active phase of protests for the authorities in the future. Protests can acquire a symbolic character that is dangerous and painful for the authorities.

Undoubtedly, this also requires a broader public consensus. In this sense, the potential of Russian protests leaves its researchers a big mystery.

\section{REFERENCES}

Assmann A. (2016), New dissatisfaction with memorial culture, Moscow.

Bakhtin M. (1975), Questions of literature and aesthetics, Moscow.

Belousov A. B., Davydov D. A., Kochukhova E. S. (2020), Post-Materialist Trend: Motivation for Protests in the Drama Theatre Square in Yekaterinburg, "Monitoring of Public Opinion: Economic and Social Changes", No. 6, DOI: 10.14515/monitoring.2020.6.1694.

Chomsky N. (2003), On Nature and Language, Cambridge.

Debor G. (2011), Society of the spectacle, Moscow.

Durkheim E. (2020), Suicide, AST, Moscow.

Garr T. (2005), Why Men Rebel, Piter?, Sant-Petersburg.

Ivanov V. (1994), Native and universal, Moscow.

Kanetti E. (1997), Masse and Power, Moscow.

Lotman Yu. (2015), Conversations about Russian culture: Life and traditions of the Russian nobility (18 - the beginning of the 19th century), Sant-Petersburg.

More than a third of those who came to Pushkinskaya Square participated in a protest action for the first time (2021), "Novaya Gazeta", https://novayagazeta.ru/news/2021/01/25/167379-issledovanie-bolee-treti-prishedshih-na-pushkinskuyu-ploschad-vpervye-uchastvovali-v-protestnoy-aktsii $(01.02 .2021)$.

Podvintsev O. B. (2014), Governors - "Varangians": tendencies of coexistence and interaction with regional elites. The governor's corps in the context of the transformation of the political system of the Russian Federation, Perm.

Rovnensky A. (2021), List of detainees at rallies in protests support of Alexei Navalny on January 23, 2021, https://ovdinfo.org/news/2021/01/23/spisok-zaderzhannyh-na-akciyah-v-podderzhku-alekseya-navalnogo-23-yanvarya-2021-goda (01.02.2021).

Scheler M. (1999), Ressentiment in the structure of morals, Sant-Petersburg.

Shults E. (2018), Radical Mass Forms of Social Protest and Legitimacy Problems, "RUDN Journal of Political Science", Vol. 4, No. 2, DOI: 10.22363/2313-1438-2018-20-2-237-245.

Skiperskikh A. V. (2020), Carnival Legitimacy in Modern Russia: New Governor`s Dresses, "Politbook", No. 4.

The exact data on those detained after the protest of supporters of Navalny in Lipetsk has not been announced (2021), Gorod 48, https://gorod48.ru/news/1908496/ (03.02.2021). 
The number of people detained at an unauthorized protest in Kazan increased to 400 (2021), KazanFirst, https://kazanfirst.ru/news/538786 (03.02.2021).

Viroli M. (2014), The Liberty of Servants, Moscow.

Zakharov S. M. (2014), Post-Soviet Democratization in the Context of Parallels Structures, "Bulletin of Kemerovo State University", No. 2-1 (58).

Zakharov S. M. (2017), Student youth in political processes in the post-Soviet space, Lipetsk.

\begin{abstract}
In this article, the author analyzes the protest activity in Russia in January-February 2021. Protest activity came to Russia after A. Navalny's investigation of V. Putin's palace in Gelendzhik. Like the Belarusian protests in August 2021, the Russian protests were suppressed by the police.

A feature of the Russian protests was their mass character. A large number of cities in almost all Russian regions were involved in the protest. Based on the data of secondary analysis, the author tries to give his own research of the Russian protest activity in January-February 2021. Protest activity in a number of Russian regions did not look accidental. One could observe protest activity in them before, but with a different agenda. The factor of unpopular government is of great importance in regional protests. The authorities no longer have the proper stock of legitimacy. This fully applies to the governors appointed by V. Putin, and, often, not directly related to the regions that have their own specificity.

Case studies of protests in Russian regions show new trends. The protests are increasingly carnival-like. Power is ridiculed and discussed with irony. Familiar dialogue with the authorities is confirmed in various forms and languages of protest.

From the author's point of view, protest activity in Russia will increase by the fall of 2021. In September 2021, elections to the Russian Parliament are to be held. The author assumes that disappointment with the authorities in Russia will grow. The social base of new protests can be broader.
\end{abstract}

Keywords: authority, Belarus, carnival, discourse, legitimacy, Navalny, Putin, regional protests, Russia

\title{
PASJA DO PALACU PUTINA PROTESTY POLITYCZNE WE WSPÓŁCZESNEJ ROSJI
}

\section{STRESZCZENIE}

W artykule tym autor poddaje analizie ruchy protestu, które wystąpiły w Rosji pomiędzy styczniem a lutym 2021 r. Bezpośrednią przyczyną protestów było śledztwo przeprowadzone przez A. Navalnego dotyczące rezydencji prezydenta Federacji Rosyjskiej W. Putina w Gelendzhik. Podobnie jak na Białorusi w sierpniu 2021 r., tak i w Rosji, protesty zostały stłumione przez policję. Te ostatnie cechowały się masowym udziałem Rosjan, a do protestów doszło w wielu miastach na terenie całego kraju. W swym badaniu autor posłużył się danymi wtórnymi. Protesty, do których doszło w wielu rosyjskich regionach pomiędzy styczniem a lutym $2021 \mathrm{r}$. nie miały znamion przypadkowości. Protestującym nie podoba się polityka władz zarówno na poziomie centralnym, jak i na poziomie lokalnym. Władze w znacznym stopniu straciły legi- 
tymację do sprawowania swych rządów. Proces ten znajduje odzwierciedlenie w nominacjach gubernatorskich, które są funkcją decyzji politycznych Kremla, często nieuwzględniających lokalnej specyfiki poszczególnych regionów kraju. Analiza wspomnianych protestów ukazuje wystąpienie nowych trendów. Protesty te coraz częściej przybierały formę heppeningu, gdzie uczestnicy wyśmiewali absurdy władzy przy pomocy humoru, kalamburów oraz innych zabaw językowych. Zdaniem autora, protesty w Rosji będą przybierać na sile na jesieni $2021 \mathrm{r}$. Ma to związek z wrześniowymi wyborami parlamentarnymi, które doprowadzą do wzrostu niezadowolenia z polityki władz rosyjskich.

Słowa kluczowe: władza, Białoruś, karnawał, dyskurs, legitymizacja, Nawalny, Putin, protesty regionalne, Rosja 